\title{
Frequency-Dependent Recruitment of Fast Amino Acid and Slow Neuropeptide Neurotransmitter Release Controls Gonadotropin-Releasing Hormone Neuron Excitability
}

\author{
Xinhuai Liu (刘新槐), ${ }^{1}$ Robert Porteous, ${ }^{1}$ Xavier d'Anglemont de Tassigny, ${ }^{2}$ William H. Colledge, ${ }^{2}$ Robert Millar, ${ }^{3}$ \\ Sandra L. Petersen, ${ }^{4}$ and Allan E. Herbison ${ }^{1}$ \\ ${ }^{1}$ Centre for Neuroendocrinology and Department of Physiology, University of Otago School of Medical Sciences, Dunedin 9054, New Zealand, \\ ${ }^{2}$ Reproductive Physiology Group, Department of Physiology, Development, and Neuroscience, University of Cambridge, Cambridge CB2 3EG, United \\ Kingdom, ${ }^{3}$ Centre for Integrative Physiology, University of Edinburgh and University of Cape Town/Medical Research Council Receptor Biology Group, \\ University of Cape Town, South Africa, and ${ }^{4}$ Department of Veterinary and Animal Sciences, University of Massachusetts Amherst, Amherst, \\ Massachusetts 01003
}

The anteroventral periventricular nucleus (AVPV) is thought to play a key role in regulating the excitability of gonadotropin-releasing hormone $(\mathrm{GnRH})$ neurons that control fertility. Using an angled, parahorizontal brain slice preparation we have undertaken a series of electrophysiological experiments to examine how the AVPV controls GnRH neurons in adult male and female mice. More than half (59\%) of GnRH neurons located in the rostral preoptic area were found to receive monosynaptic inputs from the AVPV in a sex-dependent manner. AVPV stimulation frequencies $<1 \mathrm{~Hz}$ generated short-latency action potentials in GnRH neurons with GABA and glutamate mediating $>90 \%$ of the evoked fast synaptic currents. The AVPV GABA input was dominant and found to excite or inhibit GnRH neurons in a cell-dependent manner. Increasing the AVPV stimulation frequency to $5-10 \mathrm{~Hz}$ resulted in the appearance of additional poststimulus inhibitory as well as delayed excitatory responses in $\mathrm{GnRH}$ neurons that were independent of ionotropic amino acid receptors. The inhibition observed immediately following the end of the stimulation period was mediated partly by $\mathrm{GABA}_{\mathrm{B}}$ receptors, while the delayed activation was mediated by the neuropeptide kisspeptin. The latter response was essentially absent in Gpr54 knock-out mice and abolished by a Gpr54 antagonist. Together, these studies show that AVPV neurons provide direct amino acid and neuropeptidergic inputs to GnRH neurons. Low-frequency activation generates predominant GABA/glutamate release with higher frequency activation recruiting release of kisspeptin. This frequency-dependent release of amino acid and neuropeptide neurotransmitters greatly expands the range of AVPV control of GnRH neuron excitability.

\section{Introduction}

Although the gonadotropin-releasing hormone ( $\mathrm{GnRH})$ neuron is undoubtedly the key cell type responsible for regulating fertility in mammals, it is becoming increasingly clear that specific inputs to these cells play essential roles in generating appropriate pulsatile and surge patterns of GnRH release. One such input identified more than 30 years ago (Wiegand et al., 1980) is the anteroventral periventricular nucleus (AVPV). This nucleus, sitting at the front of the rostral periventricular region of the third ventricle, is thought to play a key role in the integration of circadian and gonadal steroid information necessary for the preovulatory $\mathrm{GnRH} /$ luteinizing hormone (LH) surge in rodents (Levine, 1997; Simerly, 2002; Petersen et al., 2003; Wintermantel et al., 2006; Her-

\footnotetext{
Received Nov. 2, 2010; revised Dec. 7, 2010; accepted Dec. 10, 2010.

These studies were supported by the New Zealand Health Research Council and National Institutes of Health Grant HD027305 to S.L.P. We thank Drs. Richard Piet and Karl Iremonger for commenting on the manuscript.

Correspondence should be addressed to Prof. Allan E. Herbison, Centre for Neuroendocrinology, Department of Physiology, University of Otago School of Medical Sciences, P.0. Box 913, Dunedin 9054, New Zealand. E-mail: allan.herbison@stonebow.otago.ac.nz.

DOI:10.1523/JNEUROSCI.5759-10.2011

Copyright $\odot 2011$ the authors $\quad 0270-6474 / 11 / 312421-10 \$ 15.00 / 0$
}

bison, 2008). There is also growing evidence supporting a role for the AVPV in the activation of GnRH neurons at the time of puberty (Clarkson et al., 2009a).

Previous tract-tracing studies have indicated that AVPV neurons project directly to $\mathrm{GnRH}$ neurons in the rodent $(\mathrm{Gu}$ and Simerly, 1997; Simonian et al., 1999; Polston and Simerly, 2006; Wintermantel et al., 2006). Mapping experiments have identified cell populations in the AVPV that express the amino acid transmitters GABA and glutamate (Ottem et al., 2004) in addition to multiple different neuropeptides (for review, see Herbison, 1998), including kisspeptin, the most potent activator of the GnRH neuron discovered to date (Han et al., 2005). However, the neurochemical identity of the AVPV input to GnRH neurons and its effects on the electrical excitability of $\mathrm{GnRH}$ neurons remain unknown. Further, the AVPV is sexually dimorphic, being larger in females than males, and this has long been proposed to underlie the sexually dimorphic nature of the LH surge mechanism (Herbison, 1998; Simerly, 2002). Whether this sexual dimorphism extends to AVPV inputs to GnRH neurons is not known.

The current series of studies was undertaken to establish the nature of the AVPV input to GnRH neurons and its effects on 
their electrical excitability. Because of the proposed sexually dimorphic nature of this input, studies were undertaken to compare male and female mice. As the firing frequency of AVPV neurons alters throughout the estrous cycle (Ducret et al., 2010), and AVPV cells have the potential to release both amino acid and neuropeptide neurotransmitters, we questioned whether different AVPV firing frequencies would generate patterns of neurotransmitter release that would differentially modulate GnRH neuron excitability.

\section{Materials and Methods}

Experimental animals. Adult C57BL/6J GnRHgreen fluorescent protein (GFP) mice (Spergel et al., 1999) ( $n=128$, 63 female, 65 male; mean \pm SEM age $81 \pm 2 \mathrm{~d}$ ) were housed under $12 \mathrm{~h}$ light/dark cycles (lights on at 7:00 A.M.) with ad libitum access to food and water. A cross of GnRH-GFP and Gpr54 knock-out (Seminara et al., 2003) mouse lines was undertaken for the last series of experiments and generated mutant GnRH-GFP-Gpr54 $4^{-1-}$ and control GnRH-GFP-Gpr54 ${ }^{+/+}$mice. All experimentation was approved by the University of Otago Animal Welfare and Ethics Committee. The estrous cycle stage of female mice was determined by daily vaginal smear and mice were used on diestrus. Mice were killed between 10:30 and 11:00 A.M.

Brain slice preparation and electrophysiology.

In a series of preliminary experiments we found that conventional coronal or parasagittal brain slice preparations were not suitable for examining AVPV inputs to GnRH neurons. In the course of this work we developed an angled horizontal brain slice preparation that overcame these difficulties (Fig. 1A,B). The dissected brain was glued to an aluminum platform raised at an angle of $\sim 18^{\circ}$ as shown in Figure $1 A$, before being submerged in the cooled $\left(\sim 4^{\circ} \mathrm{C}\right.$ ) artificial CSF (aCSF) equilibrated with $95 \% \mathrm{O}_{2}, 5 \% \mathrm{CO}_{2}$ and containing high $(6 \mathrm{~mm}) \mathrm{MgCl}_{2}$ and low $(0.5$ $\mathrm{mm}) \mathrm{CaCl}_{2}$. Angled parahorizontal brain sections were then cut at 400 $\mu \mathrm{m}$ with a vibratome (Leica VT1000S) and the two topmost sections were used for recordings (slice 1 and 2 in Fig. $1 A, B$ ). The orientation of these two slices through the AVPV and surrounding structures is indicated in Figure $1 B$. Slice 1 contains the most rostral aspects of the AVPV and ventral-most GnRH neurons, whereas slice 2 contains the more caudal AVPV and parts of the periventricular nucleus of the preoptic area (PvPO) along with more dorsally located GnRH neurons.

Brain slices were incubated for at least $1 \mathrm{~h}$ in equilibrated $\left(95 \% \mathrm{O}_{2}, 5 \%\right.$ $\mathrm{CO}_{2} ; 30^{\circ} \mathrm{C}$ ) aCSF, containing (in $\mathrm{mm}$ ): $118 \mathrm{NaCl}, 3 \mathrm{KCl}, 2.5 \mathrm{CaCl}_{2}, 1.2$ $\mathrm{MgCl}_{2}, 11$ D-glucose, 10 HEPES, and $25 \mathrm{NaHCO}_{3}$, before being transferred to a submerged recording chamber where they were perfused with aCSF at $2-3 \mathrm{ml} / \mathrm{min}$, maintained at $32 \pm 1^{\circ} \mathrm{C}$. Whole-cell or loose-patch recordings of $\mathrm{GnRH}$ neurons were undertaken using a fixed-stage upright fluorescence microscope (BX51WI; Olympus) with GFP-tagged $\mathrm{GnRH}$ neurons identified briefly using fluorescence and then patched under Nomarski differential interference contrast optics (a 40× waterimmersion objective). Patch pipettes were pulled from glass capillaries (inner diameter, $1.18 \mathrm{~mm}$; outer diameter, $1.5 \mathrm{~mm}$ ) with a microelectrode puller (Sutter Instruments) and had 1.8-3.5 $\mathrm{M} \Omega$ resistances when filled with the pipette solution composed of the following (in $\mathrm{mM}$ ): 135 $\mathrm{KCl}, 5 \mathrm{NaCl}, 0.22 \mathrm{CaCl}_{2}, 10 \mathrm{HEPES}, 1$ BAPTA, $2 \mathrm{MgATP}, 0.2 \mathrm{Na}_{2} \mathrm{ATP}$, $0.2 \mathrm{Na}_{2} \mathrm{GTP}, 7$ phosphocreatine-Tris, pH 7.35 adjusted by $\mathrm{KOH}(\sim 290$ $\mathrm{mOsmol})$. For loose-patch recordings, the components of the pipette solution were (in mM): $145 \mathrm{NaCl}, 3 \mathrm{KCl}, 2.5 \mathrm{CaCl}_{2}, 10 \mathrm{HEPES}, 1.2 \mathrm{MgCl}_{2}$, $\mathrm{pH} 7.35$ adjusted by $\mathrm{NaOH}$ ( $\sim 290 \mathrm{mOsmol})$. Signals (voltage and cur- rent) were amplified with a Multiclamp 700B (CV7B; Molecular Devices) and sampled on-line using a Digidata 1440A interface (Molecular Devices) connected to a personal computer. Signals were filtered (3 or 10 $\mathrm{kHz}$; Bessel filter of Multiclamp 700B) before being digitized at a rate of 1 or $10 \mathrm{kHz}$. Acquisition and subsequent analysis of the acquired data were performed with the Clampex 10 suite of software (Molecular Devices) and Origin pro 7.5 (OriginLab). Resting membrane potentials $(-55.5 \pm 01.3 \mathrm{mV}, n=54)$ were recorded in current clamp without applying any holding current and were not corrected for the liquid junction potentials of $\sim-3 \mathrm{mV}$. The input resistance $\left(R_{\mathrm{in}}=944 \pm 53 \mathrm{M} \Omega\right.$, $n=129)$ was determined by Clampex 10 membrane test while holding the cell at $-70 \mathrm{mV}$. During experiments, the access resistance $\left(R_{\mathrm{a}}=\right.$ $11.5 \pm 1.1 \mathrm{M} \Omega, n=129)$ was checked regularly, and if a $>15 \%$ change in $R_{\mathrm{a}}$ was found, the cell was discarded.

Electrical and glutamate puff stimulation of AVPV. The AVPV was stimulated by placing a bipolar Tungsten electrode (West30.2A10, MicroProbes for Life Science) at the rostral-most edge of the third ventricle, ipsilateral to the recorded GnRH neuron (Fig. 1C). To test for connectivity between the AVPV and a GnRH neuron, square-wave current pulses $(0.2 \mathrm{~ms}$ duration) at $0.033 \mathrm{~Hz}$ were generated by a Grass S88X stimulator and current isolator Grass SIV-C (Grass Technologies). The spread of stimulation current is proportional to the intensity of the current applied (Bagshaw and Evans, 1976). To determine the minimum current intensity that would evoke synaptic currents in a GnRH neuron, we began AVPV stimulation with a low current intensity of $10 \mu \mathrm{A}$. If responses were detected, the intensity was reduced in $1 \mu \mathrm{A}$ increments to determine the minimal threshold current required to activate the $\mathrm{GnRH}$ neuron. If the $10 \mu \mathrm{A}$ current did not evoke a response it was increased in $10 \mu \mathrm{A}$ increments up to $100 \mu \mathrm{A}$, and then followed by $100 \mu \mathrm{A}$ increments up to $1 \mathrm{~mA}$ and, rarely, then increased by $1 \mathrm{~mA}$ increments up to a maximum of $9 \mathrm{~mA}$. Having determined the threshold current to evoke a response, the current intensity was then set at the threshold $(37 \% \mathrm{GnRH}$ neurons) or at no $>2 \times$ the threshold ( $63 \%$ GnRH neurons) current for the rest of the experiment. In cell-attached recordings, the effects of 1, 5, and $10 \mathrm{~Hz}$ trains were examined by delivering 50 single square-wave 
current pulses (0.2 ms duration, 500-600 $\mu \mathrm{A})$ over 50, 10, and $5 \mathrm{~s}$, respectively.

To address the possibility that the electrical stimulation of the AVPV was generating its effects by activating fibers passing through the AVPV, rather than AVPV cell bodies, we undertook a series of experiments in which a puff of glutamate was applied to the AVPV and the effect on GnRH neurons observed. In $12 \mathrm{GnRH}$ neurons, the tip of a glass pipette filled with 1 or $2 \mathrm{~mm}$ glutamate diluted with equilibrated $\left(95 \% \mathrm{O}_{2}, 5 \%\right.$ $\mathrm{CO}_{2} ; 30^{\circ} \mathrm{C}$ ) aCSF was positioned between the two poles of a bipolar Tungsten electrode located in the AVPV as usual. After the observation of stable synaptic currents induced by electrical stimulation of AVPV, the tip of the glutamate-containing pipette was then brought to touch the AVPV and puffs (duration of $100-600 \mathrm{~ms}$, each puff separated by $60 \mathrm{~s}$ ) of glutamate were delivered onto the AVPV by PV820 Pneumatic PicoPump with pressure set at 10PSI (World Precision Instruments).

Stock solutions of 6-cyano-7-nitroquinoxaline-2,3-dione (CNQX), D-2-amino-5-phosphonovaleric acid (AP5), gabazine, bicuculline, $\mathrm{BaCl}_{2}$ (all Sigma Ltd), and CGP 55845 (Tocris Bioscience) were prepared in double distilled $\mathrm{H}_{2} \mathrm{O}$ at $10^{3}$ times final concentration. A stock solution of the Gpr54 antagonist peptide 318 ( $1 \mathrm{~mm}$, Prof. R. Millar, Edinburgh, UK) was prepared in $20 \%$ propylene glycol diluted in double distilled $\mathrm{H}_{2} \mathrm{O}$. All stock solutions were stored at $-20^{\circ} \mathrm{C}$. All drugs were applied in the perfusion solution with final concentration as indicated.

Analysis. The effects of AVPV activation on GnRH neurons were determined by analyzing currents activated in GnRH neurons or, in loosepatch, the effects on firing frequency and patterning of firing. Current characteristics were assessed by analyzing traces made from averaging 5 consecutive trials repeated every $30 \mathrm{~s}$ while holding at $-70 \mathrm{mV}$, unless indicated otherwise. For firing analysis, a period $>4$ min before and immediately following the AVPV stimulation was used. Individual action potentials and bursts ( $\geq 3$ action potentials with Poisson surprise factor $>1$ ) were detected by Clampfit. The firing frequency was quantified as mean frequency [number of AP divided by collection time (seconds)], instantaneous frequency [reciprocal of interaction potential interval (seconds)], and instantaneous frequency within burst [reciprocal of interaction potential interval within a burst (seconds)]. When the instantaneous frequency after the train was greater than that before the train ( $p<0.05$, Mann-Whitney test) and this cell was considered to have been activated by the AVPV.

Dual-labeling immunocytochemistry. To help visualize the AVPV and GnRH neurons in the angled horizontal brain slice preparation we undertook dual-label immunocytochemistry for GnRH and kisspeptin. The kisspeptin neurons are located exclusively within the AVPV and PvPO in the rostral hypothalamus (Clarkson et al., 2009b). Two intact female C57BL/6J mice were perfused with $4 \%$ paraformaldehyde, and their brains were processed sequentially for $\mathrm{GnRH}$ (LR1 antisera) followed by kisspeptin (AC566 antisera) peroxidase/diaminobenzidine immunocytochemistry. Each of these staining procedures has been reported in detail previously (Herbison et al., 2008; Clarkson et al., 2009b). Brains were cut in the horizontal plane at $40 \mu \mathrm{m}$ thickness using the same $18^{\circ}$ angle cut.

\section{Results}

Dual-labeling immunocytochemistry demonstrated that the two angled parahorizontal brain sections used in these experiments contained both kisspeptin- and GnRH-immunoreactive cells (Fig. 1D). The kisspeptin labeling also confirmed that our placement of the bipolar stimulating electrode in brain tissue immediately adjacent to the rostral-most pole of the third ventricle (Fig. 1C) targeted the AVPV (Fig. 1D).

For electrophysiology, the two $400-\mu \mathrm{m}$-thick acute brain slices prepared from each animal were found to have up to 6 GnRH neurons that could be recorded. Stimulation of the AVPV resulted in the activation of synaptic currents in 77 of $129(60 \%)$ $\mathrm{GnRH}$ neurons recorded in whole-cell mode. The median current intensity of AVPV stimulation required to activate currents in GnRH neurons was $600 \mu \mathrm{A}$. No relationship was found be- tween the latency of the response in GnRH neurons and the distance between the electrode and GnRH neuron (range 50-1000 $\mu \mathrm{m}$ ) or stimulus intensity (range $2-1000 \mu \mathrm{A}$; data not shown). The percentage of GnRH neurons activated by AVPV stimulation was the same in slice 1 (ventral-most, 59\%, $n=74$ ) and slice 2 (dorsal-most; $60 \%, n=55$; Fig. $1 A, B$ ). The precise locations of individual $\mathrm{GnRH}$ neurons within the rostral preoptic area (rPOA) activated by AVPV stimulation were not predictable, with GnRH neurons both near and distant to the stimulation site being activated (Fig. 1C).

\section{Monosynaptic connections between AVPV and the majority of GnRH neurons}

Three types of electrical responses were observed in GnRH neurons following stimulation of the AVPV at $0.033 \mathrm{~Hz}$ (Fig. $2 A-C$ ). In 77 of $129(60 \%)$ GnRH neurons obtained from both male and female mice, and recorded in the whole-cell configuration, AVPV stimulation resulted in the appearance of synaptic currents following the stimulation artifact (Fig. 2A). These picoampere currents, exhibiting fast onset and slow offset, were of slightly variable latency and could sometimes evoke a single action potential in the recorded cell (Fig. 2A). A second response observed in $37(29 \%)$ of the GnRH neurons was attributable to the direct activation of their cell body or dendrite by the stimulating electrode. In this case, a very large current (nanoampere) was observed immediately following the stimulus artifact in the GnRH neuron, and this response failed to follow repeated AVPV stimulation (Fig. $2 B$ ). It could also be abolished by holding the recorded cell to $-30 \mathrm{mV}$ to inactivate voltage-dependent sodium channels (Fig. 2 B). The third type of response was seen in only 9 (7\%) of the GnRH neurons and resulted from the likely activation of their axon. The response consisted of a delayed ( $\sim 2 \mathrm{~ms})$ large (nanoampere) current that was able to follow up to $100 \mathrm{~Hz}$ AVPV stimulation (Fig. $2 C)$. Cells showing no response $(n=6)$, or either the direct or antidromic activation, were not considered further.

To examine the responses of synaptically activated GnRH neurons in more detail, we recorded from 16 cells with currents being digitized at $50 \mathrm{kHz}$, instead of the usual $10 \mathrm{kHz}$, and activated them with 4 AVPV stimuli (p1-p4) at $10 \mathrm{~Hz}$ (Fig. 2D). Fourteen of these GnRH neurons exhibited a relatively constant latency between the stimulus artifact and evoked current, with the latency at $\mathrm{p} 1$ being $2.68 \pm 0.22 \mathrm{~ms}$ and variation for the next 3 pulses being $0.1 \pm 0.02 \mathrm{~ms}, 0.11 \pm 0.02 \mathrm{~ms}$, and $0.09 \pm 0.02 \mathrm{~ms}$, respectively (Fig. 2D2). These responses with short, relatively constant latencies are highly indicative of the presence of a monosynaptic connection (Berry and Pentreath, 1976). In the remaining 2 of the $16 \mathrm{GnRH}$ neurons (14\%), the synaptic currents had longer, more variable latencies [latency at p1: $6.30 \pm 1.61 \mathrm{~ms}$, with differences between $\mathrm{p} 1$ and its consecutive pulses (p2, p3, p4) being $0.31 \pm 0.08 \mathrm{~ms}, 0.38 \pm 0.10 \mathrm{~ms}, 0.39 \pm 0.07 \mathrm{~ms}$, respectively; data not shown]. The longer and more variable latency is likely to indicate polysynaptic transmission. From the total of $77 \mathrm{GnRH}$ neurons detected to have synaptic currents following AVPV stimulation, 11 cells (14\%) exhibited variable latencies of $>5 \mathrm{~ms}$. Thus, the great majority $(n=66)$ of $\mathrm{GnRH}$ neurons recorded in this study appear to be monosynaptically activated by AVPV stimulation.

To address the issue of AVPV specificity in our electrical stimulation protocol, five GnRH neurons located 250-450 $\mu \mathrm{m}$ from the AVPV were patched and the effect of electrical activation of the AVPV was determined. Next, the stimulating electrode was carefully removed from the AVPV and placed in the lateral pre- 
optic area (LPOA) at an equal distance from the GnRH neuron (Fig. 2E1), and stimulation was applied at the same parameters used for the AVPV. The LPOA has recently been shown to provide a GABAergic input to GnRH neurons (Penatti et al., 2010). While stimulation of the LPOA was found to activate currents in GnRH neurons, these were much smaller in amplitude than that observed following AVPV stimulation (mean current amplitude $19 \pm 8 \mathrm{pA}$ for LPOA vs $169 \pm 10$ pA for AVPV; Fig. 2E2) and had a longer mean latency $(5.9 \pm 0.4 \mathrm{~ms}$ vs $2.2 \pm 0.4$ $\mathrm{ms})$. These observations suggest that the stimulation protocol used here is selectively activating AVPV inputs and that the density or impact of inputs to the GnRH neuron from the AVPV is different from those of the adjacent LPOA.

To address the issue of potential activation of axons of passage through the AVPV by our electrical stimulation protocol, 7 GnRH neurons located 250-550 $\mu \mathrm{m}$ from the AVPV were recorded and the effect of electrical activation of the AVPV was detected (Fig. 2 F1). After a stable electrical activation was achieved, a pipette placed between the two poles of the stimulating electrode was used to puff glutamate onto the AVPV. In all $7 \mathrm{GnRH}$ neurons, glutamate puffs evoked synaptic currents (Fig. 2F2,F3) in GnRH neurons that had a latency of $450 \sim 950 \mathrm{~ms}$, and were abolished by gabazine (data not shown). The latency of activation of $\mathrm{GnRH}$ neurons by puffs of glutamate was longer than that of electrical stimulation, and this likely reflects the fact that the physical spread of glutamate into the slice is much slower than that of the electrical current.

GnRH neurons receive both GABAergic and glutamatergic inputs from

\section{AVPV neurons}

The neurochemical identity of monosynaptic inputs from the AVPV to GnRH neurons was assessed using antagonists specific for the $\mathrm{GABA}_{\mathrm{A}}$ (bicuculline and gabazine), NMDA (AP5), and AMPA/kainate $(\mathrm{CNQX})$ receptors. To examine both GABAergic and glutamatergic synaptic currents, a KCl-based pipette solution was used, so that both components would have the same reversal potential $(\sim 0 \mathrm{mV})$. Cells were activated by AVPV stimulation at $0.033 \mathrm{~Hz}$, and the effects of $\mathrm{GABA}_{\mathrm{A}}$ receptor and combined NMDA/AMPA antagonists were tested on the synaptic current. Where a glutamate component was found, the effects of AMPA and NMDA were tested individually, when possible. Half of the GnRH neurons (19 of 38) were found to have a near exclusive GABAergic input from the AVPV (Fig. $3 A$ ) with $89 \pm 2 \%$ of current blocked by a GABA receptor antagonist, no glutamate component, and the remain-

E1

E2 stimulation electrode.
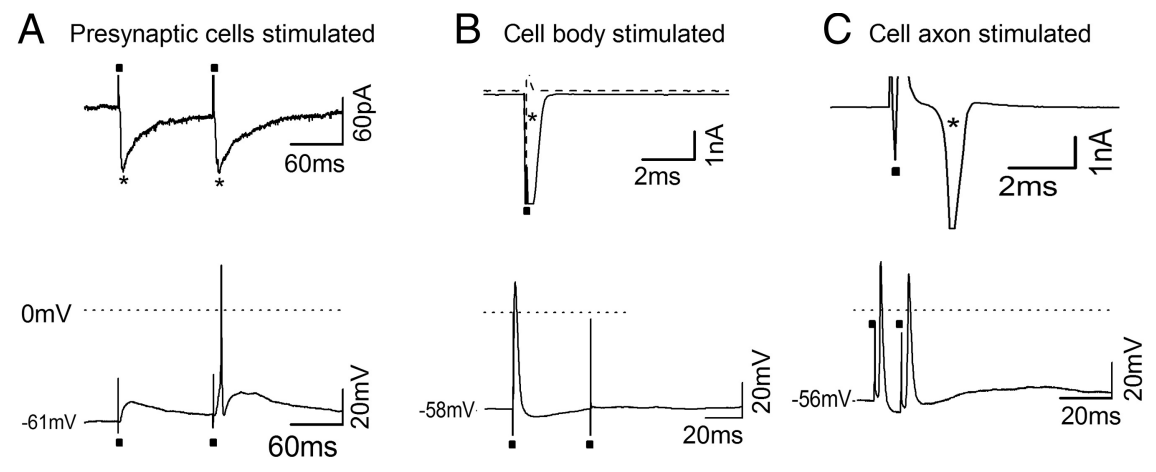

D1 D2
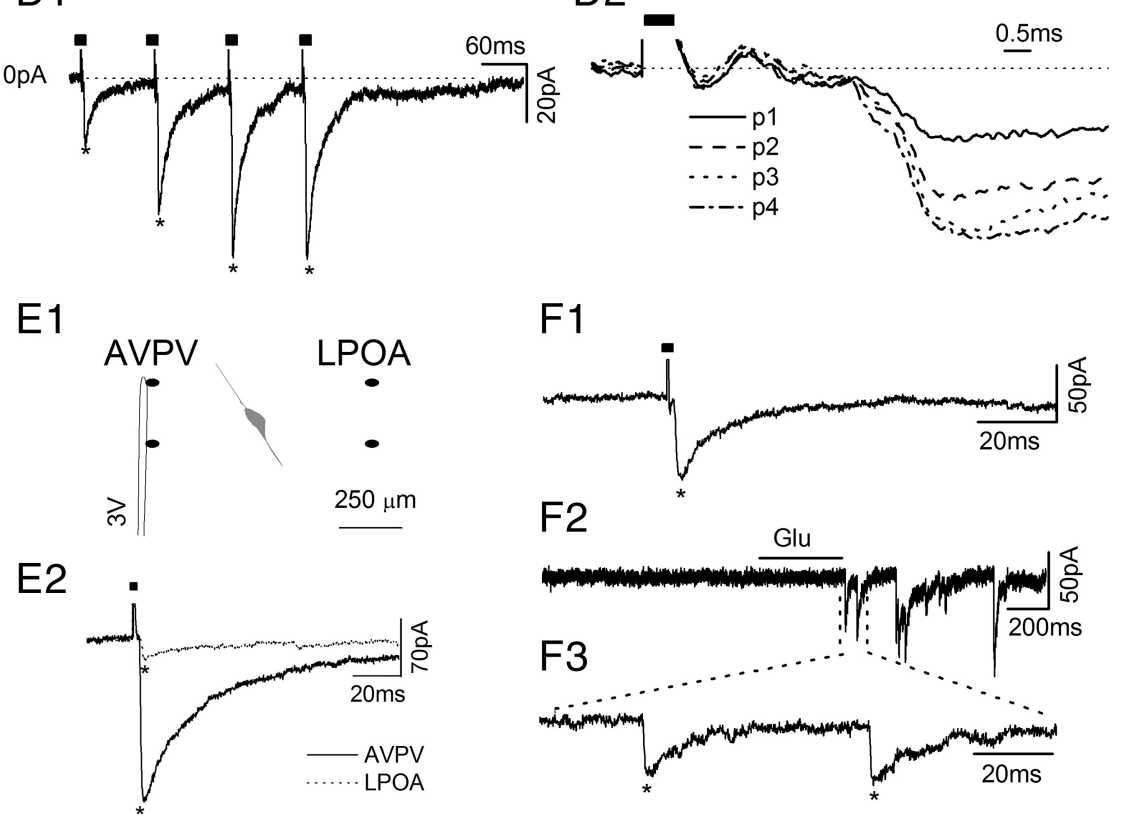

Figure 2. Monosynaptic connections exist between GnRH neurons and AVPV neurons. All stimulation artifacts (partly removed) are indicated by filled squares $(\boldsymbol{\square})$ while the response of cell is indicated by ${ }^{*}$. $\boldsymbol{A}$, Current (upper) and voltage (lower) traces from a GnRH neuron that was activated synaptically by AVPV stimulation. In one case the evoked current was able to trigger an action potential. $\boldsymbol{B}$, Current trace (upper) from a GnRH neuron that had its cell body or dendrite activated by AVPV stimulation. This response disappeared when the cell was held at $-30 \mathrm{mV}$ (dashed line). Lower trace shows voltage trace with the action potential immediately following first pulse but failing at the second pulse $30 \mathrm{~ms}$ later, indicating the evoked action potential was unable to follow high-frequency stimulation and it was not an antidromic action potential spike. C, Traces from a GnRH neuron that likely had its axon stimulated by the AVPV stimulation. Upper trace (current) shows the activation of a very large current (*truncated at $4 \mathrm{nA}$ ) with a delay of $\sim 2 \mathrm{~ms}$. Lower trace (voltage) shows that this can follow high-frequency $(100 \mathrm{~Hz})$ stimulation, suggesting antidromic nature. D, Monosynaptic currents in GnRH neurons. D1, Current trace showing that the synaptic current evoked in GnRH neurons can follow 4 pulses ( $p 1-p 4$ ) at $10 \mathrm{~Hz}$ stimulation with only a small variance of latency. D2, The same currents with baseline reset to zero and overlaid. $\mathbf{D} 1$ and $\mathbf{D 2}$ have the same amplitude scale but different time scale. $\boldsymbol{E}$, The specificity of electrical stimulation. E1, Schematic diagram showing the anatomical relationship between a recorded GnRH neuron (gray) and the location of the stimulating electrode in the AVPV and LPOA. E2, Representative current traces from a GnRH neuron activated by the AVPV (solid line) and then LPOA (dotted line). 3 V, Third ventricle. $\boldsymbol{F}$, Representative current traces from a GnRH neuron activated by AVPV electrical stimulation (F1) and then a puff of glutamate (F2, expanded in $\boldsymbol{F} 3)$ into the AVPV area between two poles of electrical

ing $11 \pm 2 \%$ residual current not attributable to GABA or glutamate signaling (Fig. $3 A$ ). The synaptic currents in the other main subpopulation of $\mathrm{GnRH}$ neurons ( 17 of $38 ; 45 \%$ ) were found to result from both $\mathrm{GABA}_{\mathrm{A}}$ and glutamate receptor activation with $62 \pm 7 \%$ of the current blocked by a $\mathrm{GABA}_{\mathrm{A}}$ antagonist, $31 \pm 7 \%$ blocked by CNQX/AP5, and $7 \pm 1 \%$ of the current unaccounted for (Fig. 3B). In two (5\%) GnRH neurons an almost exclusive glutamatergic input was identified (Fig. 3C,D). Further analysis of $8 \mathrm{GnRH}$ neurons exhibiting a glutamatergic component showed that 5 of $8(63 \%)$ were attributable to sole AMPA activa- 
A

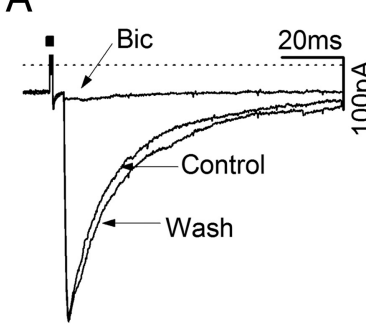

D

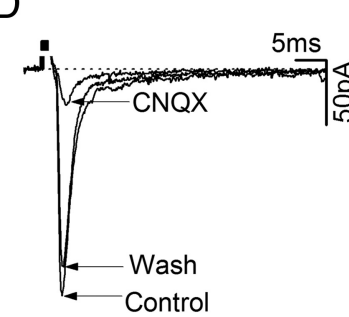

$B$

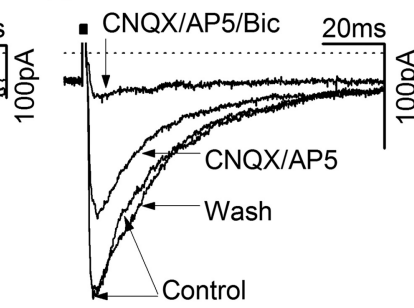

$E$

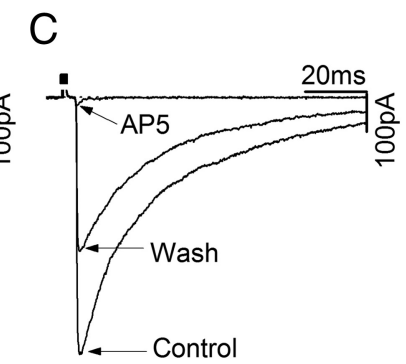

$\mathrm{F}$
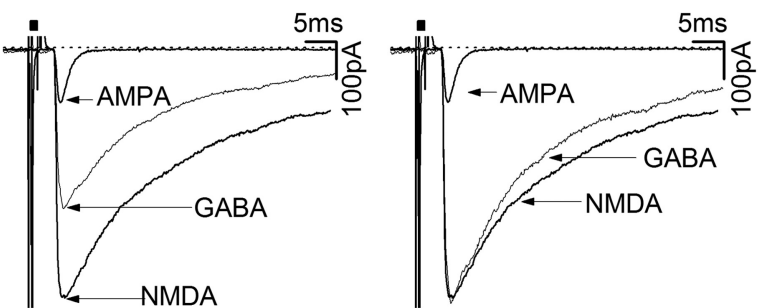

Figure 3. GABA, AMPA and NMDA-mediated synaptic currents in GnRH neurons following single pulse stimulation of AVPV Dotted-lines above traces indicate 0 PA. A, Current traces showing a synaptic current evoked in a GnRH neuron that was dependent entirely upon $G_{A B A_{A}}$ receptors. $B$, Current traces showing synaptic currents were dependent upon both $G_{A B A_{A}}$ and ionotropic glutamate receptors. $\boldsymbol{C}$, Current traces showing a rare synaptic current consisting entirely of NMDA receptor-mediated components. $\boldsymbol{D}$, Current traces showing a synaptic current that was largely mediated by AMPA receptors. $\boldsymbol{E}$, Diagram showing the overlay of pure AMPA, GABA and NMDA currents. $\boldsymbol{F}$, Diagram showing the overlay of pure AMPA, GABA and NMDA currents but with GABA and NMDA amplitude normalized to the same value. All currents were recorded while holding cell at $-70 \mathrm{mV}$.

Table 1. Summary of AVPV evoked synaptic current kinetics in GnRH neurons

\begin{tabular}{|c|c|c|c|c|c|c|}
\hline & $n$ & Latency (ms) & $\begin{array}{l}\text { Amplitude } \\
\text { (pA) }\end{array}$ & $\begin{array}{l}\text { Rise time } \\
\text { (ms) }\end{array}$ & $\begin{array}{l}\text { Half-width } \\
\text { (ms) }\end{array}$ & $\begin{array}{l}\text { Decay time } \\
\text { (ms) }\end{array}$ \\
\hline$B A$ & 25 & $3.87 \pm 0.35$ & $290 \pm 58$ & \pm 0.16 & $19.04 \pm 2.14$ & $24.41 \pm 2.75$ \\
\hline UPA & 7 & $4.47 \pm 0.77$ & $100 \pm 27$ & $0.73 \pm 0.07$ & $4.17 \pm 0.67$ & $5.20 \pm 1.27$ \\
\hline NMDA & 5 & $4.30 \pm 0.91$ & $434 \pm 132$ & $0.60 \pm 0.37$ & $15.50 \pm 4.87$ & $22.50 \pm 6.27$ \\
\hline
\end{tabular}

Table 2. AVPV evoked synaptic current in GnRH neurons of adult male and female mice

\begin{tabular}{lllrrr}
\hline & \% GABA & \% Glutamate & \% Residual & \% NMDA & \multicolumn{1}{c}{ \% AMPA } \\
\hline Male (22,17) & $68.1 \pm 6.9$ & $23.3 \pm 7.3$ & $8.7 \pm 1.4$ & $4.2 \pm 3.1$ & $23.5 \pm 9.4$ \\
Diestrus (17,12) & $77.0 \pm 5.7$ & $12.8 \pm 6.0$ & $10.2 \pm 1.9$ & $11.4 \pm 8.6$ & $2.2 \pm 2.2$ \\
\hline
\end{tabular}

Numbers in parentheses, $n$ (first for GABA, glutamate analysis; and second for NMDA, AMPA analysis).

tion (Fig. 3D) and 3 (27\%) resulted from sole NMDA receptor activation (Fig. 3C). Curiously, no GnRH neurons were detected in which both AMPA and NMDA receptors contributed to the glutamate current.

To test the possibility that NMDA currents were not detected because of $\mathrm{Mg}^{2+}$ block, $10 \mathrm{GnRH}$ neurons were tested in aCSF containing $0 \mathrm{mM} \mathrm{Mg}^{2+}, 3.7 \mathrm{mM} \mathrm{Ca}^{2+}$, and $10 \mu \mathrm{M}$ glycine. However, this failed to reveal any NMDA component in AVPV activations of GnRH neurons. The other possibility, that the NMDA current may have been hidden in the GABA current, is unlikely as the $\mathrm{GABA}_{\mathrm{A}} I-V$ curve was found to be linear between $-40 \mathrm{mV}$ and $-100 \mathrm{mV}(n=10)$.

To examine the characteristics of evoked $\mathrm{GABA}_{\mathrm{A}}$, NMDA, and AMPA synaptic currents, recordings from $25 \mathrm{GnRH}$ neurons were selected at random and subtractive analysis was used to define the current attributable to each receptor (Fig. 3 E, F; Table 1). The latency from AVPV activation of the three amino acid currents in GnRH neurons was the same at 3.9-4.5 ms (Table 1). The main comparative features of these currents are shown in Figure $3 E$ and Table 1; AMPA currents were relatively small in amplitude $(\sim 100 \mathrm{pA})$, with a short halfwidth $(\sim 4 \mathrm{~ms})$ and fast decay $(\sim 5 \mathrm{~ms})$ compared with either NMDA- or $\mathrm{GABA}_{\mathrm{A}}$ receptor-mediated currents that had large amplitudes (>300 pA) and slow decays (>20 ms) (Table 1). These differences between AMPA current kinetics and those of the other amino acid receptors are more striking when the currents are scaled to the same amplitude (Fig. $3 F$ ).

\section{Sex differences in AVPV glutamate and GABA inputs to GnRH neurons}

Previous studies have highlighted marked sex differences in the volume of the AVPV (Simerly, 2002), indicating that the AVPV input to $\mathrm{GnRH}$ neurons may be sexually dimorphic. Whole-cell recordings from 78 male and 51 diestrous female $\mathrm{GnRH}$ neurons were compared. The percentage of $\mathrm{GnRH}$ neurons exhibiting synaptic currents following $0.033 \mathrm{~Hz}$ AVPV stimulation was not different between males (59\%) and females (56\%). However, the mean AVPV stimulus threshold required to synaptically activate a GnRH neuron was different in male and female mice $(527 \pm 113$ vs $311 \pm 103 \mu \mathrm{A}$, respectively; $p<0.05$, Mann-Whitney $U$ test $)$ despite the mean distance between the stimulating electrode and recorded GnRH neuron being the same in the two sexes $(544 \pm 44$ vs $493 \pm 40 \mu \mathrm{m}$, respectively). A pharmacological analysis of the $\mathrm{GABA}_{\mathrm{A}}$ and glutamate receptors underlying these currents was possible in 22 male and 17 female GnRH neurons and revealed no significant differences, with $\sim 70 \%$ of current deriving from $\mathrm{GABA}_{\mathrm{A}}, 20 \%$ from glutamate, and 10\% from residual unknown neurotransmitter receptors in both sexes (Table 2). Further analysis of the nature of the glutamate current in 17 male and 12 diestrous female GnRH neurons showed a nonsignificant trend toward high AMPA, low NMDA in males compared with low AMPA, high NMDA in females (Table 2).

\section{Effects of AVPV stimulation on GnRH neuron excitability}

The above studies demonstrated that $0.033 \mathrm{~Hz}$ electrical activation of the AVPV generated responses in GnRH neurons that were almost entirely the result of $\mathrm{GABA}_{\mathrm{A}}$ and glutamate receptor activation. To examine the effects of these monosynaptic GABA and glutamate AVPV inputs on GnRH neuron firing rate, we performed a series of loose-patch experiments that allow recordings to be made of $\mathrm{GnRH}$ neurons without disturbing their intracellular environment. The AVPV was stimulated in current increments (as above, starting at $100 \mu \mathrm{A}$ ) until a response was obtained (threshold stimulus). Cells that did not respond to $9 \mathrm{~mA}$ current intensity were considered to be nonresponding cells. Responding cells were activated by trains of 5 AVPV stimulations at $0.033 \mathrm{~Hz}$ (median current $800 \mu \mathrm{A}$ ) using a submaximal threshold stimulus so that not every AVPV stimulation generated an action potential (Fig. $4 A, B$, controls). The effects of $\mathrm{GABA}_{\mathrm{A}}$ receptor antagonists (bicuculline or gabazine) and the glutamate receptor antagonist mixture (CNQX plus AP5) were then tested on AVPV-evoked firing.

Twenty-four GnRH neurons activated by AVPV stimulation (mean latency $4.9 \pm 1.2 \mathrm{~ms}$ ) were tested with $\mathrm{GABA}_{\mathrm{A}}$ receptor antagonists, and three different responses were encountered. The 
predominant response $(n=15,63 \%)$ involved the suppression of AVPV-evoked action potentials by bicuculline or gabazine in a reversible manner (Fig. 4A). This indicated that part of the activating effects of AVPV stimulation on GnRH neurons was mediated by $\mathrm{GABA}_{\mathrm{A}}$ receptors. Because ongoing glutamatergic signaling in the brain slice can modulate the effects of exogenous GABA on GnRH neurons (Moenter and DeFazio, 2005), we checked these responses in the presence and absence of CNQX/AP5. However, the ability of the $\mathrm{GABA}_{\mathrm{A}}$ antagonists to suppress the AVPV response occurred both in the presence (Fig. $4 A)$ and absence of CNQX/AP5. The second response encountered $(n=4)$ was the exact opposite, with $\mathrm{GABA}_{\mathrm{A}}$ receptor antagonists increasing the ability of AVPV activation to initiate action potentials in $\mathrm{GnRH}$ neurons (Fig. $4 B$ ). Finally, 5 GnRH neurons activated by the AVPV were unaffected by $\mathrm{GABA}_{\mathrm{A}}$ receptor blockers.

For $8 \mathrm{GnRH}$ neurons in which $\mathrm{GABA}_{\mathrm{A}}$ receptor antagonists suppressed their response to the AVPV stimulation, it was possible to repatch the GnRH neuron in whole-cell mode, and the nature of the synaptic current from the AVPV was determined. Seven of these GnRH neurons were shown to have $>96 \%$ of the current mediated by $\mathrm{GABA}_{\mathrm{A}}$ receptors, while the others were mixed, with $86 \%$ dependent upon $\mathrm{GABA}_{\mathrm{A}}$ receptors.

Twelve GnRH neurons activated by the AVPV (mean latency $5.1 \pm 1.3 \mathrm{~ms}$ ) were tested with CNQX/AP5 and, again, three different responses were detected. In $3 \mathrm{GnRH}$ neurons (25\%) CNQX/AP5 increased the response to AVPV stimulation and also reduced the latency variance (Fig. $4 A$ ). In 2 cells $(17 \%)$ CNQX/AP5 decreased the response to AVPV stimulation, while the remaining 7 (58\%) GnRH neurons activated by the AVPV were unaffected by CNQX/AP5.

\section{Frequency-dependent activation of GnRH neurons by AVPV stimulation}

The above studies demonstrate that monosynaptic amino acid inputs from the AVPV are able to regulate the excitability of $\mathrm{GnRH}$ neurons. However, in addition to GABA and glutamate, the AVPV contains a large number of neurons that express many different neuropeptides (Herbison, 1998). It is generally held that higher frequencies of firing are required to activate significant neuropeptide release (Andersson et al., 1982; Lundberg and Hökfelt, 1983). Furthermore, a recent study has shown that most AVPV neurons in the mouse fire in a relatively regular pattern at $\sim 1-2 \mathrm{~Hz}$, with episodes of firing up to $8 \mathrm{~Hz}$ (Ducret et al., 2010). Accordingly, we have examined here the effects of 1,5 , and $10 \mathrm{~Hz}$ AVPV activation $(50 \times$ $500 \mu \mathrm{A}$ pulses over 50,10 , and $5 \mathrm{~s}$ ) on GnRH neuron excitability in loose-patch recording mode.

\section{$1 \mathrm{~Hz}$}

A total of $23 \mathrm{GnRH}$ neurons were recorded while the AVPV was activated by two sets of $1 \mathrm{~Hz}$ stimulations. Although some GnRH neurons were found to exhibit action potentials during the $50 \mathrm{~s}, 1$ $\mathrm{Hz}$ AVPV stimulation, this stimulation protocol had no effect on subsequent GnRH neuron firing rate in any cell (data not shown). Neither silent nor spontaneously active GnRH neurons were activated subsequent to the AVPV stimulation (Table 3 ).

\section{$5 \mathrm{~Hz}$}

As with the $1 \mathrm{~Hz}$ stimulation, some GnRH neurons exhibited action potentials coupled to individual stimuli within the two sets of $5 \mathrm{~Hz}$ AVPV stimulation. However, 5 of 24 (21\%) GnRH neurons also responded with a delayed $(87 \pm 21 \mathrm{~s})$ and relatively prolonged ( $11.7 \pm 2.5 \mathrm{~min}$; range from 5 to $20 \mathrm{~min}$ ) increase in GnRH neuron firing rate (Fig. $5 A$ ). Four of the responding cells (that were spontaneously active) exhibited a brief period of inhibition of firing immediately after the AVPV activation (Fig. 5A). The remaining $19 \mathrm{GnRH}$ neurons (5 silent and 14 spontaneously active) exhibited no subsequent change in firing rate following AVPV stimulation. When considered as a whole, the $5 \mathrm{~Hz}$ activation of the AVPV had no significant effect upon subsequent mean or intraburst firing frequency of $\mathrm{GnRH}$ neurons, but did significantly $(p<0.05)$ increase instantaneous frequency that represents firing rate only when active (Table 3 ).

\section{$10 \mathrm{~Hz}$}

Sixteen (5 silent and 11 spontaneously active) of 34 (47\%) GnRH neurons responded to one or two trains of $10 \mathrm{~Hz}$ stimulation of the AVPV with a long-lasting increase in firing (Fig. $5 B$ ). This response had a delay of $55 \pm 7 \mathrm{~s}$ and lasted for $12.0 \pm 1.6 \mathrm{~min}$ (range 5-30 $\mathrm{min}$ ). In four spontaneously active cells, an inhibition of firing was observed immediately after the stimulus period (Fig. 5B) similar to that following $5 \mathrm{~Hz}$ stimulation. In terms of the delayed, long-lasting excitation, the mean frequency, instantaneous frequency, and frequency within bursts were all significantly $(p<0.001)$ increased by the $10 \mathrm{~Hz}$ stimulation train (Table 3; Fig. 5F, G). Interestingly, the same response was observed in females and males with, respectively, 6 of $13(46 \%)$ and 10 of $21(48 \%)$ GnRH neurons exhibiting poststimulus excita- 
Table 3. Effects of 1, 5, and $10 \mathrm{~Hz}$ activation of the AVPV on subsequent firing rates of GnRH neurons

\begin{tabular}{|c|c|c|c|c|c|c|}
\hline & $1 \mathrm{~Hz}(23)$ & & $5 \mathrm{~Hz}(24)$ & & $10 \mathrm{~Hz}(34)$ & \\
\hline & Pre & Post & Pre & Post & Pre & Post \\
\hline Instant frequency & $1.08 \pm 0.33$ & $1.21 \pm 0.37$ & $1.07 \pm 0.31$ & $1.67 \pm 0.44^{*}$ & $1.44 \pm 0.33$ & $2.05 \pm 0.34^{* * *}$ \\
\hline Mean frequency & $0.23 \pm 0.10$ & $0.28 \pm 0.12$ & $0.27 \pm 0.12$ & $0.31 \pm 0.13$ & $0.29 \pm 0.09$ & $0.67 \pm 0.17^{* * *}$ \\
\hline Intraburst frequency & $1.25 \pm 0.40$ & $1.50 \pm 0.45$ & $1.59 \pm 0.49$ & $2.07 \pm 0.53$ & $2.12 \pm 0.46$ & $3.08 \pm 0.48^{* * *}$ \\
\hline
\end{tabular}

Values in parentheses are number of neurons. ${ }^{*} p<0.05,{ }^{* * *} p<0.001$ compared with prestimulation period (paired-sample Wilcoxon tests).
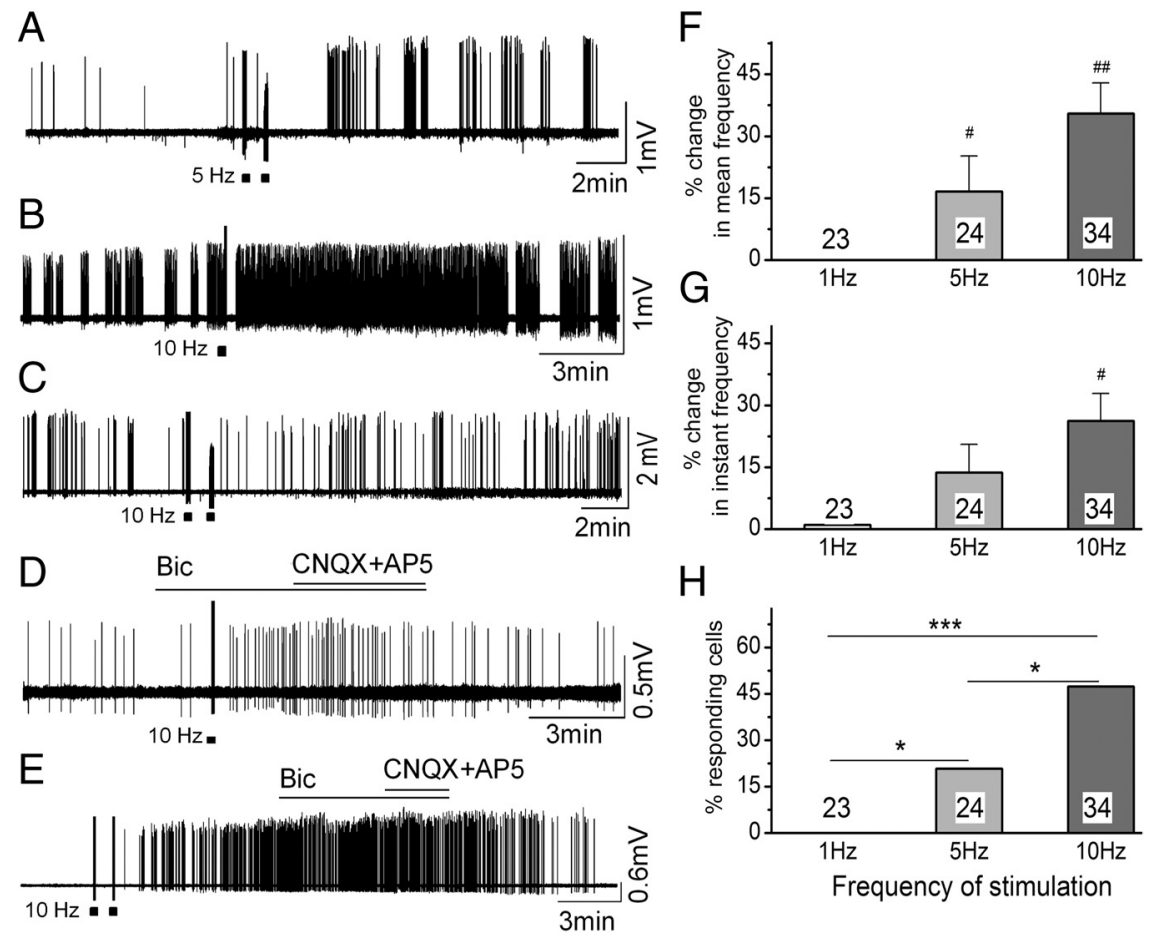

$\mathrm{H}$

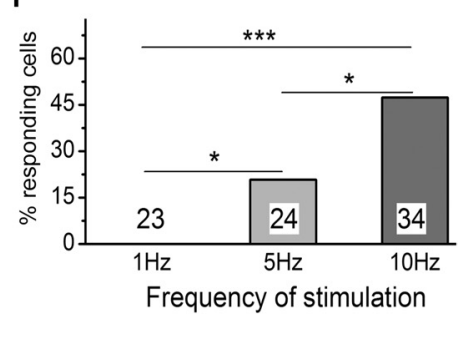

Figure 5. Frequency-dependent activation of GnRH neuron firing following AVPV stimulation. Filled squares indicate the one or two periods of 5 or $10 \mathrm{~Hz}$ AVPV activation. $\boldsymbol{A}-\boldsymbol{C}$, Examples of poststimulus firing patterns evoked by $5 \mathrm{~Hz}(\boldsymbol{A})$ and $10 \mathrm{~Hz}(\boldsymbol{B}, \boldsymbol{C})$ activation of the AVPV using loose-patch recordings of GnRH neurons. $\boldsymbol{D}, \boldsymbol{E}$, treatment of $\mathrm{GnRH}$ neurons with a mixture of amino acid blockers either before or after $10 \mathrm{~Hz}$ activation does not prevent the poststimulus excitation. $\boldsymbol{F}-\boldsymbol{H}$, Histograms showing analysis of poststimulus mean firing rate, instantaneous frequency and percentage responding cells to 1,5 and $10 \mathrm{~Hz}$ activation of the AVPV. $n$ is given at the base of each histogram. ${ }^{*} p<0.05,{ }^{* * *} p<0.001$ (Fisher's exact test). ${ }^{\#} p<0.05,{ }^{\# \#} p<0.001$ compared with $1 \mathrm{~Hz}$ stimulation (Kruskal-Wallis ANOVA).

tion. We retested the effects of $10 \mathrm{~Hz}$ AVPV activation after the initial excitatory effect had subsided in $6 \mathrm{GnRH}$ neurons but were unable to initiate the same response. Two cells $(6 \%)$ responded to the AVPV stimulation with a subsequent decrease in firing rate (Fig. 5C). As with the 1 and $5 \mathrm{~Hz}$ stimulation, $\sim 50 \%$ of $\mathrm{GnRH}$ neurons exhibited action potentials during the 5 and $10 \mathrm{~Hz}$ AVPV stimulation. However, the ability to respond to individual AVPV stimulations did not predict the poststimulus response of the GnRH neuron.

To examine the involvement of GABA and glutamate in the poststimulation response, $\mathrm{GnRH}$ neurons were activated by 10 $\mathrm{Hz}$ AVPV stimulation in the presence of the amino acid receptor antagonists. Regardless of whether the antagonists were applied together or sequentially, either before (Fig. 5D) or during activation (Fig. 5E), we found CNQX/AP5/bicuculline to have no effects upon the subsequent activation of GnRH neurons by $10 \mathrm{~Hz}$ AVPV stimulation. The silent period sometimes observed immediately after the $10 \mathrm{~Hz}$ AVPV stimulation remained in the presence of the mixture of CNQX/AP5/bicuculline (data not shown; $n=4)$. However, the duration of the silent period was reduced in the presence of the $\mathrm{GABA}_{\mathrm{B}}$ receptor antagonist $(2 \mu \mathrm{M}$,
CGP55845, Fig. 6F) in all 3 GnRH neurons tested that exhibited the poststimulus inhibition.

The percentage of GnRH neurons that responded to 1,5 , and $10 \mathrm{~Hz}$ activation of the AVPV with the delayed activation showed a clear frequency-response relationship, with $0 \%$ responding to $1 \mathrm{~Hz}$, $21 \%$ responding to $5 \mathrm{~Hz}$ ( $p<0.05$ vs 1 $\mathrm{Hz})$, and $48 \%$ responding to $10 \mathrm{~Hz}(p=$ 0.05 vs $5 \mathrm{~Hz}, p<0.001$ vs $1 \mathrm{~Hz}$; Fig. $5 H$ ).

Activation of GnRH neurons following AVPV stimulation is mediated by kisspeptin-Gpr54 signaling

The relatively intense activation of $\mathrm{GnRH}$ neurons for up to $30 \mathrm{~min}$ after AVPV stimulation had a number of features reminiscent of the effects of exogenous kisspeptin on GnRH neurons (Han et al., 2005). Accordingly, we tested whether kisspeptin-Gpr54 signaling may be involved in this response in two different ways.

In the first, we repeated the $10 \mathrm{~Hz}$ stimulation experiments in male and female knock-out (GnRH-GFP-Gpr54 ${ }^{-/-}$) and control (GnRH-GFP-Gpr54 ${ }^{+/+}$) mice. Baseline recordings showed similar patterns of GnRH neuron firing in knock-out and control mice. Twelve (67\%) of 18 knock-out and $11(73 \%)$ of 15 control $\mathrm{GnRH}$ neurons were spontaneously active. While mean and instantaneous firing rates were the same, the intraburst frequency was lower $(1.3 \pm 0.3$ $\mathrm{Hz} ; n=12)$ in knock-out mice compared with controls $(3.1 \pm 0.6$ $\mathrm{Hz} ; n=11 ; p<0.01$, Mann-Whitney test). Stimulation of the AVPV at $10 \mathrm{~Hz}$ in littermate control mice resulted in the typical poststimulus increase in firing (Fig. 6A) in 6 of 15 (40\%) GnRH neurons ( $n=4,1$ male, 3 female), with a percentage of responding cells (Fig. 6D) and percentage change in mean frequency (Fig. $6 E$ ) similar to those of GnRH neurons from normal GnRH-GFP mice. In contrast, in GnRH-GFP-Gpr54 ${ }^{-1-}$ mice ( $n=4$, 2 each sex; Fig. $6 B, E$ ), the same stimulation protocol was found to stimulate firing in only 1 of 18 (6\%) GnRH neurons. Overall, GnRHGFP-Gpr54 ${ }^{-1-}$ mice displayed markedly reduced numbers of responding cells (Fig. $6 D, p<0.01$ ) and essentially no change in mean firing frequency (Fig. $6 E, p<0.01$ ) compared with wildtype littermate GnRH-GFP mice.

In the second experiment, we used normal GnRH-GFP mice and used a novel Gpr54 antagonist peptide 318 (P318). Antagonist 318 is derived from antagonist 234 (Roseweir et al., 2009), but in contrast to 234, which exhibits agonistic activities at $>1$ $\mu \mathrm{M}, 318$ is a pure antagonist with an increase in potency of $>10$ - 
fold (our unpublished observation). To establish whether the poststimulus excitation was generated by kisspeptin, P318 (10 or $50 \mathrm{~nm}$ ) was added to the bath aCSF before and during the $10 \mathrm{~Hz}$ stimulation. Treatment with 50 nм P318 resulted in complete blockade of the poststimulus firing increase in $\mathrm{GnRH}$ neurons to the same level as in Gpr54-knock-out mice (Fig. 6D,E). Only 1 of $18 \mathrm{GnRH}$ neurons (6\%) showed an increase in firing after 10 $\mathrm{Hz}$ stimulation in the presence of $\mathrm{P} 318$ and, overall, there was no mean increase in firing rate $(-5 \pm 7 \%)$ compared with $47 \%$ responding GnRH neurons exhibiting a $36 \pm 7 \%$ increase in firing for controls $(p<0.01$; Fig. $6 D, E)$. Although 10 nм P318 also reduced poststimulus firing frequency to $16 \pm 11 \%$, it did not result in a significant change compared with controls (Fig. $6 D, E$ ).

\section{Discussion}

We describe here an angled parahorizontal brain slice preparation that has allowed the effects of AVPV inputs to GnRH neurons to be examined. The majority of $\mathrm{GnRH}$ neurons in the rPOA receive direct, monosynaptic inputs from AVPV neurons, and low-frequency $(<1 \mathrm{~Hz})$ stimulation of these inputs evokes an almost exclusive amino acid-mediated regulation of GnRH neuron excitability. The predominant neurotransmitter in this pathway is GABA, and it appears to both enhance and suppress GnRH neuron excitability. The AVPV amino acid input to GnRH neurons was found to be quantitatively different between the sexes. At higher AVPV stimulation frequencies $(5-10 \mathrm{~Hz})$, we also observed a long-lasting activation in $\sim 50 \%$ of GnRH neurons that was subsequently shown to depend upon the kisspeptin receptor Gpr54. Together these observations characterize the physiologically important AVPV input to rPOA GnRH neurons and reveal its frequency-dependent influence upon the excitability of GnRH neurons.

In early experiments we were unable to activate $\mathrm{GnRH}$ neurons by AVPV stimulation in coronal or parasagittal brain slices. Reexamining the topography of GnRH neurons in relation to the AVPV, we decided that an angled horizontal slice might be preferable and this was proven to be the case. We found that $\sim 60 \%$ of rPOA GnRH neurons in this preparation receive direct monosynaptic synaptic inputs from the AVPV. The regional specificity of our stimulation protocol was supported by experiments showing that LPOA and AVPV activation evoked different patterns of synaptic input in the same GnRH neuron. Furthermore, we were able to activate synaptic inputs to GnRH neurons with puffs of glutamate in the AVPV demonstrating that neurons in this area, rather than axons of passage, are innervating GnRH neurons. We also note that no clear topographical relationship existed for rPOA GnRH neurons activated by the AVPV. While it is possible that all GnRH neurons receive an AVPV input in the intact brain, the observation of randomly located GnRH neurons with AVPV inputs is compatible with the similarly random location of c-Fos-

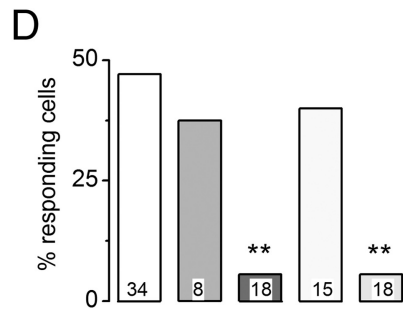

E
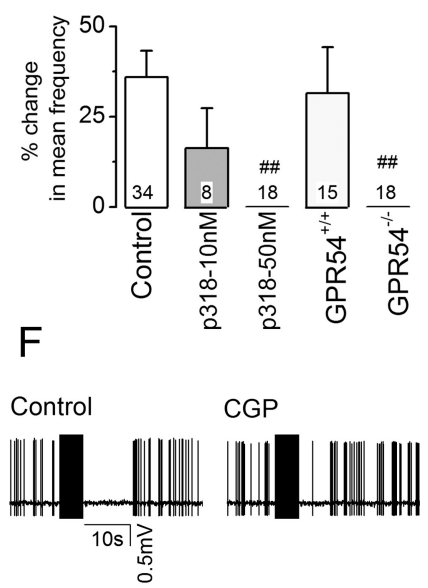

Figure 6. Absence of AVPV-evoked poststimulus excitation in GnRH neurons from Gpr54 knock-out mice and in the presence of a application of the Gpr54 antagonist (p318). A, Poststimulus firing pattern evoked by $10 \mathrm{~Hz}$ activation of the AVPV in control $\mathrm{GnRH}$ neuron in control and 2 min after CGP55845 (CGP, $2 \mu \mathrm{M}$ ). Note that the duration of the immediate, short-lasting inhibition following $10 \mathrm{~Hz}$ stimulation train was reduced by CGP.

expressing rPOA GnRH neurons at the time of the GnRH surge (Hoffman et al., 1993; Wintermantel et al., 2006). These electrophysiological findings agree well with previous tract tracing studies indicating direct AVPV inputs to GnRH neurons ( $\mathrm{Gu}$ and Simerly, 1997; Simonian et al., 1999; Wintermantel et al., 2006) and provide the first electrophysiological evidence that AVPV neurons project directly to GnRH neurons.

A major finding of this study is that GABAergic neurons provide the principal input from the AVPV to GnRH neurons. Approximately half of GnRH neurons received an almost exclusive GABAergic input from the AVPV, while the remainder had a mixed GABA/glutamate input. In cell-attached current-clamp recordings, this AVPV GABA input was found to be either excitatory or inhibitory. Previous studies examining the effects of $\mathrm{GABA}_{\mathrm{A}}$ receptor activation on adult GnRH neurons have generated conflicting results (DeFazio et al., 2002; Han et al., 2002, 2004; Moenter and DeFazio, 2005), and the reasons for this discrepancy have not been resolved. Interestingly, recent investigations (Watanabe et al., 2009; Constantin et al., 2010) have reported likely depolarizing effects of $\mathrm{GABA}_{\mathrm{A}}$ receptor activation when examining intracellular calcium concentrations in adult GnRH neurons. One concern in all of these studies is that exogenous GABA is applied as an unphysiological bolus to $\mathrm{GnRH}$ neurons. Using a slice preparation that allows activation of an endogenous GABA input, we have found a predominant (60\%) stimulatory action. GnRH neurons in which $>96 \%$ of the AVPV- 
evoked synaptic current was GABAergic were found to be excited by AVPV stimulation, and this was blocked by $\mathrm{GABA}_{\mathrm{A}}$ receptor antagonists. However, a small population of GnRH neurons (15\%) responded in the opposite manner, suggestive of a classical inhibitory GABA influence. The reasons for this heterogeneity are unknown but could reflect differential dendritic/axonal damage during the slicing procedure (Nabekura et al., 2002) or variable effects of other inputs on $\mathrm{GABA}_{\mathrm{A}}$ receptor functioning.

We find here that only $\sim 33 \%$ of $\mathrm{rPOA}$ GnRH neurons are targeted by AVPV glutamatergic neurons. This result is surprising considering that glutamatergic neurons are plentiful in the AVPV (Ottem et al., 2004) and most GnRH neurons express functional glutamate receptors (Iremonger et al., 2010). Virtually all GnRH neurons exhibit spines (Campbell et al., 2005, 2009), indicative of glutamatergic inputs, and the majority exhibit electrophysiological evidence of functional glutamate receptors (Spergel et al., 1999; Christian et al., 2009). For GnRH neurons in which it was possible to differentiate between AMPA and NMDA receptor activation, $\sim 70 \%$ of the AVPV glutamate current was mediated by AMPA receptors. Intriguingly, no GnRH neurons showed AMPA and NMDA receptor coactivation following AVPV stimulation. This is reminiscent of the observation that only $19 \%$ of GnRH neurons have spontaneous postsynaptic currents mediated by both AMPA and NMDA receptors (Christian et al., 2009). The relative absence of NMDA receptor involvement is in agreement with other brain slice studies indicating that only $10-30 \%$ of adult GnRH neurons express functional NMDA receptors (Spergel et al., 1999; Christian et al., 2009; Constantin et al., 2010; Iremonger et al., 2010).

One unexpected observation has been that a small population of GnRH neurons responded to glutamate receptor antagonists with enhanced excitability and reduced action potential latency variance following AVPV stimulation. The most likely explanation of this is that glutamate neurons in the brain slice tonically excite a neuronal population that presynaptically inhibits AVPV inputs on GnRH neurons. Removal of this presynaptic inhibition would generate both reduced variance in action potential latency and stronger coupling between the AVPV input and GnRH neuron.

Some neurons corelease GABA and glutamate (Gutiérrez, 2005; Seal and Edwards, 2006), and it is proposed that AVPV $\mathrm{GABA} /$ glutamate neurons innervate GnRH neurons (Ottem et al., 2004). If GABA and glutamate were coreleased onto GnRH neurons, we would expect to find the latency and rise time of their respective synaptic currents to be the same (Gutiérrez, 2005). While this was found to be the case (Table 1), proof of corelease of glutamate and GABA onto GnRH neurons will likely only be achieved through simultaneous recordings of a $\mathrm{GnRH}$ cell and a single AVPV afferent neuron.

The AVPV is larger in the female than in the male (Simerly, 2002). We show here that a significantly greater AVPV stimulating current $(\sim 35 \%)$ was required to evoke threshold activation of synaptic currents in male versus female GnRH neurons. This result is compatible with the smaller size of the male AVPV. Put another way, had we used the same current intensity in males and females, we would have detected fewer activated GnRH neurons in the male. Once activated, however, the AVPV input in males and females appears similar in terms of its GABA/glutamate component and kisspeptin-mediated effects. Although a major sex difference exists for kisspeptin neurons in the AVPV, a small population of kisspeptin neurons does exist in the male, and they are presumably functional (Clarkson and Herbison, 2006). Over- all, these studies point to a quantitative, but, possibly not a qualitative, sex difference in AVPV inputs to GnRH neurons.

Neurons in the AVPV synthesize a variety of neuropeptides (Herbison, 1998) that may be coexpressed with GABA and/or glutamate (Hökfelt et al., 2000; Ottem et al., 2004). We find here that $5-10 \mathrm{~Hz}$ AVPV stimulation resulted in poststimulus inhibitory and excitatory actions on $\mathrm{GnRH}$ neuron firing. Long-lasting inhibitory effects were observed in a minority of GnRH neurons $(6 \%)$, and the neurotransmitters involved in these responses are not known. However, the inhibition encountered immediately following high-frequency AVPV stimulation in $\sim 30 \%$ of GnRH neurons was shown to be mediated in part by $\mathrm{GABA}_{\mathrm{B}}$ receptors. The delayed stimulatory response was observed in $21 \%$ and $47 \%$ of GnRH neurons following $5 \mathrm{~Hz}$ and $10 \mathrm{~Hz}$ AVPV stimulation, respectively. This response was very reminiscent of the effects of exogenous kisspeptin on GnRH neurons (Han et al., 2005; Zhang et al., 2008). Our studies support this interpretation since the response was almost completely abrogated in Gpr54 knock-out mice or in the presence of a Gpr54 antagonist.

Together, these data demonstrate that $1 \mathrm{~Hz}$ activity within AVPV afferents will provide low-level GABA and glutamatergic drive to GnRH neurons, whereas higher frequencies have the potential to greatly facilitate this excitation by releasing the neuropeptide kisspeptin. For some GnRH neurons there is also a $\mathrm{GABA}_{\mathrm{B}}$ receptor-mediated inhibitory restraint during highfrequency stimulation. Previous work has shown that AVPV neurons have mean firing rates of $1-2 \mathrm{~Hz}$, and these double before the generation of the GnRH surge (Ducret et al., 2010). This predicts that the AVPV regulation of GnRH neurons occurs predominantly through GABA and glutamate neurotransmission under basal conditions such as during diestrus. However, consistent with the proposed importance of kisspeptin for activation of the GnRH neurons at the time of the GnRH surge (Smith et al., 2006; Clarkson et al., 2008), the repertoire of neurotransmitters used by AVPV afferents is very likely expanded on proestrus to include kisspeptin. Although the idea of frequency-dependent release of amino acid and neuropeptide transmitters is widely accepted (Lundberg and Hökfelt, 1983), the present report provides a rare example of this principal in the mammalian CNS (Verhage et al., 1991).

\section{References}

Andersson PO, Bloom SR, Edwards AV, Järhult J (1982) Effects of stimulation of the chorda tympani in bursts on submaxillary responses in the cat. J Physiol 322:469-483.

Bagshaw EV, Evans MH (1976) Measurement of current spread from microelectrodes when stimulating within the nervous system. Exp Brain Res 25:391-400.

Berry MS, Pentreath VW (1976) Criteria for distinguishing between monosynaptic and polysynaptic transmission. Brain Res 105:1-20.

Campbell RE, Han SK, Herbison AE (2005) Biocytin filling of adult gonadotropin-releasing hormone neurons in situ reveals extensive, spiny, dendritic processes. Endocrinology 146:1163-1169.

Campbell RE, Gaidamaka G, Han SK, Herbison AE (2009) Dendrodendritic bundling and shared synapses between gonadotropin-releasing hormone neurons. Proc Natl Acad Sci U S A 106:10835-10840.

Christian CA, Pielecka-Fortuna J, Moenter SM (2009) Estradiol suppresses glutamatergic transmission to gonadotropin-releasing hormone neurons in a model of negative feedback in mice. Biol Reprod 80:1128-1135.

Clarkson J, Herbison AE (2006) Postnatal development of kisspeptin neurons in mouse hypothalamus; sexual dimorphism and projections to gonadotropin-releasing hormone neurons. Endocrinology 147:5817-5825.

Clarkson J, d'Anglemont de Tassigny X, Moreno AS, Colledge WH, Herbison AE (2008) Kisspeptin-GPR54 signaling is essential for preovulatory gonadotropin-releasing hormone neuron activation and the luteinizing hormone surge. J Neurosci 28:8691-8697. 
Clarkson J, Boon WC, Simpson ER, Herbison AE (2009a) Postnatal development of an estradiol-kisspeptin positive feedback mechanism implicated in puberty onset. Endocrinology 150:3214-3220.

Clarkson J, d'Anglemont de Tassigny X, Colledge WH, Caraty A, Herbison AE (2009b) Distribution of kisspeptin neurones in the adult female mouse brain. J Neuroendocrinol 21:673-682.

Constantin S, Jasoni CL, Wadas B, Herbison AE (2010) Gammaaminobutyric acid and glutamate differentially regulate intracellular calcium concentrations in mouse gonadotropin-releasing hormone neurons. Endocrinology 151:262-270.

DeFazio RA, Heger S, Ojeda SR, Moenter SM (2002) Activation of A-type gamma-aminobutyric acid receptors excites gonadotropin-releasing hormone neurons. Mol Endocrinol 16:2872-2891.

Ducret E, Gaidamaka G, Herbison AE (2010) Electrical and morphological characteristics of anteroventral periventricular nucleus kisspeptin and other neurons in the female mouse. Endocrinology 151:2223-2232.

Gu GB, Simerly RB (1997) Projections of the sexually dimorphic anteroventral periventricular nucleus in the female rat. J Comp Neurol 384:142-164.

Gutiérrez R (2005) The dual glutamatergic-GABAergic phenotype of hippocampal granule cells. Trends Neurosci 28:297-303.

Han SK, Abraham IM, Herbison AE (2002) Effect of GABA on GnRH neurons switches from depolarization to hyperpolarization at puberty in the female mouse. Endocrinology 143:1459-1466.

Han SK, Todman MG, Herbison AE (2004) Endogenous GABA release inhibits the firing of adult gonadotropin-releasing hormone neurons. Endocrinology 145:495-499.

Han SK, Gottsch ML, Lee KJ, Popa SM, Smith JT, Jakawich SK, Clifton DK, Steiner RA, Herbison AE (2005) Activation of gonadotropin-releasing hormone (GnRH) neurons by kisspeptin as a neuroendocrine switch for the onset of puberty. J Neurosci 25:11349-11356.

Herbison AE (1998) Multimodal influence of estrogen upon gonadotropinreleasing hormone neurons. Endocr Rev 19:302-330.

Herbison AE (2008) Estrogen positive feedback to gonadotropin-releasing hormone $(\mathrm{GnRH})$ neurons in the rodent: the case for the rostral periventricular area of the third ventricle (RP3V). Brain Res Rev 57:277-287.

Herbison AE, Porteous R, Pape JR, Mora JM, Hurst PR (2008) Gonadotropinreleasing hormone neuron requirements for puberty, ovulation, and fertility. Endocrinology 149:597-604.

Hoffman GE, Smith MS, Verbalis JG (1993) c-Fos and related immediate early gene products as markers of activity in neuroendocrine systems. Front Neuroendocrinol 14:173-213.

Hökfelt T, Broberger C, Xu ZQ, Sergeyev V, Ubink R, Diez M (2000) Neuropeptides-an overview. Neuropharmacology 39:1337-1356.

Iremonger KJ, Constantin S, Liu X, Herbison AE (2010) Glutamate regulation of GnRH neuronal excitability. Brain Res 1364:35-43.

Levine JE (1997) New concepts of the neuroendocrine regulation of gonadotropin surges in rats. Biol Reprod 56:293-302.

Lundberg JM, Hökfelt T (1983) Coexistence of peptides and classical neurotransmitters. Trends Neurosci 6:325-333.

Moenter SM, DeFazio RA (2005) Endogenous gamma-aminobutyric acid can excite gonadotropin-releasing hormone neurons. Endocrinology 146:5374-5379.

Nabekura J, Ueno T, Okabe A, Furuta A, Iwaki T, Shimizu-Okabe C, Fukuda A, Akaike N (2002) Reduction of KCC2 expression and GABAA receptor-mediated excitation after in vivo axonal injury. J Neurosci 22:4412-4417.
Ottem EN, Godwin JG, Krishnan S, Petersen SL (2004) Dual-phenotype GABA/glutamate neurons in adult preoptic area: sexual dimorphism and function. J Neurosci 24:8097-8105.

Penatti CA, Davis MC, Porter DM, Henderson LP (2010) Altered GABAA receptor-mediated synaptic transmission disrupts the firing of gonadotropin-releasing hormone neurons in male mice under conditions that mimic steroid abuse. J Neurosci 30:6497-6506.

Petersen SL, Ottem EN, Carpenter CD (2003) Direct and indirect regulation of gonadotropin-releasing hormone neurons by estradiol. Biol Reprod 69:1771-1778.

Polston EK, Simerly RB (2006) Ontogeny of the projections from the anteroventral periventricular nucleus of the hypothalamus in the female rat. J Comp Neurol 495:122-132.

Roseweir AK, Kauffman AS, Smith JT, Guerriero KA, Morgan K, PieleckaFortuna J, Pineda R, Gottsch ML, Tena-Sempere M, Moenter SM, Terasawa E, Clarke IJ, Steiner RA, Millar RP (2009) Discovery of potent kisspeptin antagonists delineate physiological mechanisms of gonadotropin regulation. J Neurosci 29:3920-3929.

Seal RP, Edwards RH (2006) Functional implications of neurotransmitter co-release: glutamate and GABA share the load. Curr Opin Pharmacol 6:114-119.

Seminara SB, Messager S, Chatzidaki EE, Thresher RR, Acierno JS Jr, Shagoury JK, Bo-Abbas Y, Kuohung W, Schwinof KM, Hendrick AG, Zahn D, Dixon J, Kaiser UB, Slaugenhaupt SA, Gusella JF, O'Rahilly S, Carlton MB, Crowley WF Jr, Aparicio SA, Colledge WH (2003) The GPR54 gene as a regulator of puberty. $\mathrm{N}$ Engl J Med 349:1614-1627.

Simerly RB (2002) Wired for reproduction: organization and development of sexually dimorphic circuits in the mammalian forebrain. Annu Rev Neurosci 25:507-536

Simonian SX, Spratt DP, Herbison AE (1999) Identification and characterization of estrogen receptor a-containing neurons projecting to the vicinity of the gonadotropin-releasing hormone perikarya in the rostral preoptic area of the rat. J Comp Neurol 411:346-358.

Smith JT, Popa SM, Clifton DK, Hoffman GE, Steiner RA (2006) Kiss1 neurons in the forebrain as central processors for generating the preovulatory luteinizing hormone surge. J Neurosci 26:6687-6694.

Spergel DJ, Krüth U, Hanley DF, Sprengel R, Seeburg PH (1999) GABAand glutamate-activated channels in green fluorescent protein-tagged gonadotropin-releasing hormone neurone in transgenic mice. J Neurosci 19:2037-2050.

Verhage M, McMahon HT, Ghijsen WE, Boomsma F, Scholten G, Wiegant VM, Nicholls DG (1991) Differential release of amino acids, neuropeptides, and catecholamines from isolated nerve terminals. Neuron 6:517-524.

Watanabe M, Sakuma Y, Kato M (2009) GABAA receptors mediate excitation in adult rat GnRH neurons. Biol Reprod 81:327-332.

Wiegand SJ, Terasawa E, Bridson WE, Goy RW (1980) Effects of discrete lesions of preoptic and suprachiasmatic structures in the female rat. Neuroendocrinology 31:147-157.

Wintermantel TM, Campbell RE, Porteous R, Bock D, Gröne HJ, Todman MG, Korach KS, Greiner E, Pérez CA, Schütz G, Herbison AE (2006) Definition of estrogen receptor pathway critical for estrogen positive feedback to gonadotropin-releasing hormone neurons and fertility. Neuron 52:271-280.

Zhang C, Roepke TA, Kelly MJ, Rønnekleiv OK (2008) Kisspeptin depolarizes gonadotropin-releasing hormone neurons through activation of TRPC-like cationic channels. J Neurosci 28:4423-4434. 